\title{
Communicative-Oriented Approach to the Study of Parts of Speech by Students of Professional College
}

\author{
Yulia Lukianets \\ Professional College of the Kyiv Institute of Intellectual Property and Law of \\ the National University "Odessa Law Academy". \\ Kharkiv highway, 210, Kyiv - 121,02121 \\ Tel./fax: (044) 5638054
}

\begin{abstract}
The role of communicative-activity approach in the process of mastering English by students on the basis of a professional college is described. The importance of focusing the English language course on the development of skills and abilities to produce their own statements in the personal and professional spheres is noted. The emphasis is placed on the content of this approach through the prism of the development of the speed of speech activity and the formation of speech patterns and structures. The orientation of the communicative-oriented approach to the formation of communicative competence, which determines the students' worldviews, the system of value orientations, the development of professional and critical thinking is considered. Six principles of the organization of educational activity of students studying English are allocated. The importance of the principle of communicative-personal organization of educational activity for realization of communicative orientation of the educational process is determined. The effectiveness of the use of game, active and interactive methods, group, pair and individual forms of work as ways to implement a communicative-oriented approach during English language learning is noted. The active role of the teacher in directing the discussion, debate or dispute in the right direction during the classroom classes using interactive methods is highlighted. The emphasis is placed on the effectiveness of modeling a communicative situation close to real life using professional vocabulary and mastering certain socio-cultural aspects. The classification of parts of speech is considered and the presence of a specific set of grammatical properties and basic syntactic functions is noted. The importance of role-playing games in the study of parts of speech by students of a professional college is considered. The examples of effective grammar games are given: ball games, dice, gifts, etc. The emphasis is placed on the effectiveness of the communicativeoriented approach in the study of parts of speech.
\end{abstract}

Keywords: part of speech, professional college, brainstorming, role play, interactive game

Постановка проблеми дослідження. Поява комунікативно-зорієнтованого підходу до вивчення частин мови в сучасній лінгводидактиці обумовлено декількома причинами. 3 одного боку, студентові необхідно опанувати мову на різних його рівнях фонетичному, лексичному, граматичному. Саме таке знання мови $є$ джерелом різнобічних знань, засобом розвитку мислення, мовлення, духовного збагачення людини. Тому для мовного розвитку студента важливо не тільки добре знання правил (лінгвістична змістова лінія), а й уміння застосовувати ці правила в повсякденній практичній мовленнєвій діяльності (мовна змістова лінія). У зв'язку з цим набуває першочергового значення проблема розвитку комунікативних умінь студентів при вивченні частин мови, коли студенти повинні отримати нові знання, вміння і навички в 
роботі над текстом, з граматики і розвитку мовлення з тим, щоб забезпечити основу для вивчення систематичного курсу англійської мови в фаховому коледжі. Особливо важливим в цьому відношенні, на наш погляд, $є$ фаховий період навчання, коли в студентів систематизуються та поглиблюються знання про частини мови і вони можуть більш усвідомлено зрозуміти їх функціональне навантаження, а значить, і ефективно використовувати в своїй промові.

Аналіз останніх досліджень і публікацій. Обрана проблематика недостатньо представлена в наукових розвідках, тому доцільно наголосити на необхідності проведення детальних досліджень в майбутньому. Проте варто відзначити дотикові дослідження наступних вчених: Вдовіна В. В., Гальскової Н. Д., Гурій М. О., Костюченко К. Є., Крушинської Н. І., Ліхошерстової В. Г., Цимбал С. В.

Мета дослідження - проаналізувати змістовне наповнення комунікативнозорієнтованого підходу до вивчення частин мови студентами фахового коледжу.

Виклад основного матеріалу. Найбільш продуктивними для навчання мови i мовлення $є$ комунікативно-діяльнісний і функціонально-комунікативний підходи, які об’єднують в єдине ціле мовний зміст курсу. Зокрема, комунікативно-діяльнісний підхід знаходить своє відображення в теорії мовної діяльності. При такому підході курс англійської мови повинен забезпечувати студентів не тільки знаннями, а й уміннями i навичками продукувати власні висловлювання різних жанрів, типів і стилів мовлення. Тому більшість мовних і мовних вправ в зв’язку з цим підходом необхідно виконувати безпосередньо для комунікації і спілкування.

Організації ефективної мовленнєвої діяльності на уроці сприяє комунікативнозорієнтований підхід у навчанні, що передбачає необхідність побудови навчального процесу як моделі спілкування. Суть даного підходу в тому, що правила, слова і вирази не вивчаються через спеціальні вправи, а засвоюються в процесі комунікативної діяльності. Тут одночасно розвивається швидкість мовлення і відпрацьовуються мовленнєві зразки і структури. Наприклад, для відпрацювання вживання модальних дієслів студентам пропонується вирішити проблеми, провести інструктаж, вивчити правила користування яким-небудь приладом (Крива, 2013).

Комунікативний підхід до навчання іноземної мови студентами фахового коледжу сприяє формуванню в них комунікативної компетентності як ключової професійної, впливає на їх світогляд, систему цінностей, уміння мислити. Поступово освоюючи 
основи комунікативної компетентності, студент досягає найвищого рівня автономності в організації своєї майбутньої діяльності, забезпечуючи собі перший крок до успіху (Гурій, 2013).

Український методист-дослідник О. Б. Тарнопольський у своєму збірнику «Методика навчання англійської мови» виділяє шість принципів організації навчальної діяльності студентів:

- принцип комунікативно-особистісної організації навчальної діяльності;

- принцип обов'язкового використання і раціонального співвідношення алгоритмічних напівевристичних і евристичних навчальних дій під час засвоєння мовленнєвої комунікації;

- принцип організації одночасної навчальної діяльності на заняттях усієї мовної групи студентів під час формування навичок і умінь;

- принцип взаємопов'язаного навчання різних видів мовленнєвої діяльності 3 урахуванням їх особливостей і прискореним навчанням сприйняття мовлення;

- принцип циклічності побудови навчального процесу;

- принцип раціонального використання рідної мови під час навчання іноземної.

Найважливішим і основним принципом є 1-й принцип, що реалізує комунікативну спрямованість навчання загалом. Для обгрунтування цього принципу слід проаналізувати, що ж $є$ комунікативною особистісною організацією навчальної діяльності (Вдовін, 2007).

Дослідивши особливості комунікативно-орієнтованого навчання, ми визначаємо комунікативно-орієнтований підхід до навчання іноземної мови студентів фахового коледжу як такий, що передбачає організацію навчання, за якого моделюються риси реального процесу спілкування. При цьому найбільш ефективними способами реалізації комунікативно-орієнтованого підходу до навчання англійської мови є застосування ігрових, активних, інтерактивних методів, використання різноманітних форм роботи (групова, парна, індивідуальна), різних методів та прийомів управління навчальною діяльністю. Перш за все повинно бути створено на заняттях доброзичливу атмосферу та умови, які б сприяли спілкуванню студентів іноземною мовою (Костюченко, 2017).

Під час проведення аудиторних занять за інтерактивною методикою викладач перестає виконувати роль єдиного та референтного джерела знань. Натомість викладач виступає активним учасником комунікативного процесу, направляючи дискусії, дебати 
чи диспути у потрібне русло, тобто виступає у ролі language facilitator. Користь такого підходу важко переоцінити, оскільки саме за таких умов студенти вчаться не лише висловлювати свою думку та відстоювати власну позицію, а й шукати шляхи вирішення певних проблемних питань власне через процес комунікації в групі. Надзвичайно дієвим за таких обставин є моделювання комунікативної ситуації, наближеної до реального життя. Саме ця методика найефективніше допомагає використати лексику за професійним спрямуванням та засвоїти певні соціокультурні аспекти (Крушинська, 2019).

Кожне слово англійської мови можна віднести до певної категорії, які називаються частинами мови (parts of speech). Вивченням частин мови в англійській мові займається такий розділ граматики, як морфологія (morphology). Всі слова англійської мови класифіковані на частини мови відповідно до трьома критеріями: граматичне значення, форма і синтаксична функція. Виходячи з цих принципів, в англійській мові існують самостійні (notional) і службові (functional) частини мови.

В англійській мові існує 8 частин мови. Розглянемо ці частини мови в загальних рисах:

1. Noun - це іменник, який коротко позначають як «N». Іменник відповідає на питання «хто?» або що?» і позначає людей або предмети. Наприклад, слова «машина», «любов», «брат» і інші є іменниками.

2. Pronoun - це займенник, яке коротко позначають як «PRN» або «PRO». Займенник також використовується для позначення людей і предметів, проте використовується для заміни іменника, наприклад, слова «він», «вона», «хтось» і інші є займенниками.

3. Verb - це дієслово, яке коротко позначають як «V». Дієслово - це слово, яке виражає дію і відповідає на питання «що робити?» або «що зробити?». Наприклад, слова «бігати», «читати», «починати» є дієсловами.

4. Adverb - це прислівник, який коротко позначають як «ADV». Прислівник відповідає на питання «Як?», «Яким чином?», «Коли?» і описує дію, виражену дієсловом. Наприклад, якщо слово «бігати» це дієслово, то в словосполученні «швидко бігати» слово «швидко» буде власною мовою, яка описує дієслово «бігати» і відповідає на питання «Як?». Інші приклади прислівники - «повільно», «зараз».

5. Adjective - це прикметник, якмй коротко позначають як «ADJ». Прикметник відповідає на питання «Який?», «Яке?», «Які?», «Яка?» і описує іменник. Наприклад, 
слова «великий», «гарний», «зелений», «сильний» і інші є прикметниками, які надають додаткові відомості про іменник.

6. Preposition - це займенник, який коротко позначають як «PREP». Це короткі слова, такі як «на», «Під» «Через», «Поруч» та інші, які традиційно використовуються перед іменниками і позначають місце, час або рух іменників.

7. Interjection - це вигук, яке коротко позначають як «INTER». Вигуки - це слова або вирази, які використовуються для позначення сильних почуттів, таких як подив, біль або страх. Наприклад, слова «Ой», «Ай», «Ух» і т.д. є вигуками.

8. Conjunction - це союз, який коротко позначають як «CONJ». Союзи з’єднують між собою слова, групи слів або пропозиції. Такі слова як «I», «Але», «Хоча», «Тому що» $є$ союзами.

3 «noun» римується «pronoun», далі йде «verb», з ним римується «proverb», потім запам'ятовуємо п’яту частину мови - «adjective», а потім три останні частини промови: «preposition», «interjection» і «conjunction». До речі, в трьох останніх частинах можна запам'ятати, що «interjection» знаходиться між «preposition» i «conjunction», як би виконуючи свою функцію з'єднання слів або груп слів.

Слова кожної лексико-граматичної категорії (частини мови) мають своїм специфічним набором граматичних властивостей i основними синтаксичними функціями. Проте, система розподілу слів на частини мови, в основі якої знаходяться універсальні принципи, допускає варіативність інтерпретації в залежності від кожного конкретного ладу, і кожного конкретного випадку, оскільки в будь-якій мові будуть зустрічатися відхилення від стереотипізації, викликаної наявністю всіх критеріїв у більшості представників того чи іншого класу слів.

Результати дослідження. Вивчення частин мови $є$ фундаментальним на різних етапах вивчення англійської мови, але при цьому є складною та багатогранною для вивчення. Для покращення вивчення іноземної мови студентами фахового коледжу в рамках комунікативно-зорієнтованого підходу доцільно використовувати різноманітні освітні інструменти.

Рольова гра є одним з активних методів навчання, який відтворює ситуації з реального життя. Вона часто використовується на заняттях з англійської мови у студентів фахового коледжу. Рольова гра підвищує рівень мотивації та зацікавленості у вивченні іноземної мови, розкриває творчий потенціал та відіграє важливу роль у підготовці студентів до 
їхнього професійного життя. Вона легко комбінується 3 іншими активними видами діяльності, як мозковий штурм і дискусія.

Рольова гра не проводиться спонтанно, викладач має поступово підготувати групу до iii проведення. Ролі, рольові дії та ситуації мають бути актуально підібрані та чітко продумані, відповідні темам занять. У процесі рольової гри викладач не коментує і не виправляє помилки студентів, а тактовно робить це після обговорення результатів гри, спонукаючи студентів до самостійного пошуку правильного варіанта (Ліхошерстова, 2020).

Процес засвоєння модальних дієслів буде цікавим і корисним, якщо дати студентам завдання написати правила, використовуючи дієслова: must, should, ought to, are allowed to, can, have to, mustn't та ін. Перефразування також сприяє засвоєнню мовних зразків i структур. Безумовно, для успішного виконання будь-якого завдання викладач повинен поставити конкретні завдання і дати зразок або алгоритм виконання (Гальскова, 2004). Здобувачам дається список «don’ts» i пропонується скласти речення 3 додатковою умовою.

Наведемо приклад ефективних граматичних ігор:

1. Гра в м’яч. Мета: автоматизація вживання форм дієслова в усному мовленні.

Хід роботи: представник першої команди придумує речення з вивченим дієсловом. Він кидає м'яч партнеру з другої команди та говорить речення, пропускаючи дієслово. Гравець, який спіймав м’яч, повторює речення, вставляючи правильну форму дієслова, кидає м'яч партнеру з першої команди і називає своє речення, не кажучи дієслово і т.д. За кожну помилку нараховується штрафний бал. Перемагає команда, яка набере найменшу кількість штрафних балів.

2. Кубики. Ціль: автоматизація вживання конструкції в усному мовленні

Хід роботи: для гри виготовляються кубики, на гранях яких наклеєні малюнки 3 зображенням предметів або тварин. Студенти діляться на дві команди. Учасники по черзі виходять до столу, підкидають кубик i називають речення 3 відпрацьованою конструкцією, відповідні сюжету малюнку на одній з граней куба. За кожне правильне придумане речення команда отримує один бал. Перемагає команда, яка набрала більшу кількість балів.

3. Подарунки. Ціль: закріплення лексики по темі, автоматизація використання використаних вивчених дієслів в майбутньому часі усному мовлені. 
Хід роботи: утворюється дві команди, На дошці записується два ряди слів: 1) найменування подарунка, 2) список дієслів. Граючі повинні сказати, використовуючи дієслова зі списку, що вони будуть робити з подарунками, які отримані на День народження. Кожен учасник гри придумує по одному реченню. Перемагає команда, яка швидше впорається з завданням і складе речення без помилок (Цимбал, 2015).

Комунікативно-зорієнтований підхід при вивченні частин мови є досить ефективним та дозволяє засвоїти складну тему в розрізі програвання конкретних ситуацій взаємодії в побутових та професійних ситуаціях.

Перспективи подальших розвідок. У подальшому доцільно акцентувати увагу на формуванні системи комунікативних вправ для всіх частин мови, яка створена 3 врахуванням можливостей та потреб студентів фахового коледжу.

\section{References}

1. Vdovin V. V. (2007) Komunikatyvnyi pidkhid yak optymalnyi zasib vyvchennia inozemnoi movy $u$ VNZ. [Communicative approach as an optimal means of learning a foreign language in higher education]. Visnyk Natsionalnoho universytetu «Lvivska politekhnika». 586. Pp. 15-20

2. Halskova N. D. (2004) Mezhkulturnoe obuchenye: problema tselei y soderzhanyia obuchenyia ynostrannbim yazikam. [Intercultural learning: the problem of goals and content of foreign language learning] Ynostrannii yazik v shkole. 1. 145-146.

3. Hurii M. O. (2013) Komunikatyvnyi pidkhid do vyvchennia dilovoi inozemnoi movy studentamy ekonomichnykh spetsialnostei. [Communicative approach to the study of business foreign language by students of economic specialties]. Pedahohichni nauky: teoriia, istoriia, innovatsiini tekhnolohii, 1 (27). 218-226

4. Kostiuchenko K. Ye. (2017) Sutnist i pryntsypy komunikatyvno oriientovanoho navchannia anhliiskoi movy. [The essence and principles of communicatively oriented learning of English]. Pedahohichnyi almanakh. 33. 64-69.

5. Kryva Ya., Mamedova O. (2015) Komunikatyvnyi pidkhid u vyvchenni anhliiskoi movy. [Communicative approach in learning English.] Taken from http://www.vtei.com.ua/doc/16.10.2015/66/6.20.pdf

6. Krushynska N. I. (2019) Suchasni pidkhody ta innovatsiini tekhnolohii formuvannia inshomovnoi komunikatyvnoi kompetentsii studentiv nemovnykh spetsialnostei. [Modern approaches and innovative technologies for the formation of foreign language communicative competence of students of non-language specialties]. Naukovi zapysky Natsionalnoho universytetu «Ostrozka akademiia»: seriia «Filolohiia». Ostroh: Vyd-vo NaUOA, 8 (76), 104-106.

7. Likhosherstova V. H. (2020) Rolova hra yak aktyvnyi metod navchannia anhliiskoi movy studentiv navchalnykh zakladiv vyshchoi osvity morskoho spriamuvannia. [Role play as an 
active method of teaching English to students of higher education in maritime education.] Naukovi zapysky Mizhnarodnoho humanitarnoho universytetu. 32. 59-62.

8. Tsymbal C. V. (2015) Rolova hra na zaniattiakh anhliiskoi movy yak element komunikatyvnoho pidkhodu do vyvchennia inozemnoi movy. [Role play in English as an element of a communicative approach to learning a foreign language]. Aktualni problemy pedahohiky, psykholohii ta profesiinoi osvity $2,41-48$

\section{Translation of the References, Title and Abstract to the Author's Language}

\section{Сиисок Посилань}

1. Вдовін В. В. (2007) Комунікативний підхід як оптимальний засіб вивчення іноземної мови у ВНЗ. Вісник Національного університету «Львівська політехніка». 586. - С. $15-20$

2. Гальскова Н. Д. (2004) Межкультурное обучение: проблема целей и содержания обучения иностранным языкам. Иностранный язык в школе. 1. 145-146.

3. Гурій М. О. (2013) Комунікативний підхід до вивчення ділової іноземної мови студентами економічних спеціальностей. Педагогічні науки: теорія, історія, інноваційні технології, 1 (27). 218-226

4. Костюченко К. С. (2017) Сутність і принципи комунікативно орієнтованого навчання англійської мови. Педагогічний альманах. 33. 64-69.

5. Крива Я., Мамедова О. (2015) Комунікативний підхід у вивченні англійської мови. Взято з http://www.vtei.com.ua/doc/16.10.2015/66/6.20.pdf

6. Крушинська Н. І. (2019) Сучасні підходи та інноваційні технології формування іншомовної комунікативної компетенції студентів немовних спеціальностей. Наукові записки Національного університету «Острозька академія»: серія «Філологія». Острог: Вид-во НаУОА, 8 (76), 104-106.

7. Ліхошерстова В. Г. (2020) Рольова гра як активний метод навчання англійської мови студентів навчальних закладів вищої освіти морського спрямування. Наукові записки Міжнародного гуманітарного університету. 32. 59-62.

8. Цимбал С. В. (2015) Рольова гра на заняттях англійської мови як елемент комунікативного підходу до вивчення іноземної мови. Актуальні проблеми педагогіки, психології та професійної освіти 2, 41-48

\section{КОМУНІКАТИВНО-ЗОРІСНТОВАНИЙ ПІДХІД ДО ВИВЧЕННЯ ЧАСТИН МОВИ СТУДЕНТАМИ ФАХОВОГО КОЛЕДЖУ}

\section{Юлія Лук'янець}

Фаховий коледж Київського інституту інтелектуальної власності та права Національного університету "Одеська юридична академія"

Харківське шосе,210, м.Київ - 121, 02121

Тел./факс: (044) 5638054 
Анотація: Охарактеризовано роль комунікативно-діяльнісного підходу в ході вивчення англійської мови студентами на базі фахового коледжу. Відзначено важливість орієнтування курсу англійської мови на розвиток умінь $і$ навичок продукувати власні висловлювання в особистій та професійній сферах. Наголошено на змістовному наповненні даного підходу через призму розвитку швидкості мовленнєвої діяльності та формуванні мовленнєвих зразків і структур. Розглянуто спрямованість комунікативно-зорієнтованого підходу на формування комунікативной компетентності, щзо обумовлює їх світоглядні уявлення, систему цุіннісних орієнтацій, розвиненість професійного та критичного мислення. Виокремлено шість принципів організації навчальної діяльності студентів при вивченні англійської мови. Визначено важливість принципу комунікативно-особистісної організачії навчальної діяльності для реалізачії комунікативної спрямованості навчального процесу. Відзначено ефективність застосування ігрових, активних, інтерактивних методів, групової, парної, індивідуальної форми роботи як способів реалізації комунікативноорієнтованого підходу в ході навчання англійської мови. Виокремлено активну роль викладача в направленні дискусії, дебатів чи диспутів у потрібне русло під час проведення аудиторних занять за інтерактивною методикою. Наголошено на дієвості моделювання комунікативної ситуації, наближеної до реального життя при використанні професійної лексики та засвоєнні певних соиіокультурних аспектів. Розглянуто класифікацію частин мови та відзначено наявність спещиифічного набором граматичних властивостей $i$ основними синтаксичними функціями. Розглянуто значення рольових ігор при вивченні частин мови студентами фахового коледжу. Наведено приклади ефективних граматичних ігор: гра в м'яч, кубики, подарунки. Наголошено на ефективності комунікативно-зорієнтованого підходу при вивченні частин мови.

Ключові слова: частина мови, фаховий коледж, мозковий итурм, рольова гра, інтерактивна гра.

\section{КОММУНИКАТИВНО-ОРИЕНТИРОВАННЫЙ ПОДХОД К ИЗУЧЕНИЮ ЧАСТЕЙ РЕЧИ СТУДЕНТАМИ ПРОФЕССИОНАЛЬНОГО КОЛЛЕДЖА}




\section{Юлия Лукьянец}

Профессиональный колледж Киевского института интеллектуальной собственности и права Национального университета "Одесская юридическая академия"

Харьковское шоссе, 210, г.Киев - 121, 02121

Тел./факс: (044) 5638054

Аннотация: Охарактеризованная роль коммуникативно-деятельностного подхода в ходе изучения английского языка студентами на базе профессионального колледжа. Отмечена важность ориентирования курса английского языка на развитие умений и навыков продуцировать собственные высказывания в личной и профессиональной сферах. Отмечено содержательное наполнение данного подхода через призму развития скорости речевой деятельности и формировании речевых образиов и структур. Рассмотрено направленность коммуникативно-ориентированного подхода на формирование коммуникативной компетентности, обусловливает их мировоззренческие представления, систему иенностных ориентаций, развитость профессионального и критического мышления. Выделены шесть принципов организации учебной деятельности студентов при изучении английского языка. Определены важность принципа коммуникативно-личностной организации учебной деятельности для реализации коммуникативной направленности учебного процесса. Отмечена эффективность применения игровых, активныхх, интерактивных методов, групповой, парной, индивидуальной формы работы как способов реализации коммуникативноориентированного подхода в ходе обучения английскому языку. Выделена активная роль преподавателя в направлении дискуссии, дебатов или диспутов в нужное русло во время проведения аудиторных занятий по интерактивной методике. Отмечено действенность моделирования коммуникативной ситуации, приближенной к реальной жизни при использовании профессиональной лексики и усвоении определенных соииокультурных аспектов. Рассмотрена классификация частей речи и отмечено наличие специфического набора грамматических свойств и основных синтаксических функиий. Рассмотрены значение ролевых игр при изучении частей речи студентами профессионального колледжа. Приведены примеры эффективных грамматических игр: игра в мяч, кубики, подарки. Отмечена эффективность коммуникативноориентированного подхода при изучении частей речи.

Ключевые слова: часть речи, профессиональный колледж, мозговой штурм, ролевая игра, интерактивная игра. 